Purdue University Purdue e-Pubs

Libraries Research Publications

$1-1-1999$

\title{
Document Delivery in Academic Fee-Based Information Services
}

Suzanne M. Ward

Purdue University, ward@purdue.edu

Mary Dugan

Purdue University, mdugan@purdue.edu

Follow this and additional works at: http://docs.lib.purdue.edu/lib_research

Part of the Library and Information Science Commons

Ward, Suzanne M. and Dugan, Mary, "Document Delivery in Academic Fee-Based Information Services" (1999). Libraries Research Publications. Paper 142.

http://docs.lib.purdue.edu/lib_research/142

This document has been made available through Purdue e-Pubs, a service of the Purdue University Libraries. Please contact epubs@purdue.edu for additional information. 


\title{
Document Delivery in Academic Fee-Based Information Services
}

\author{
Suzanne M. Ward \\ Mary Dugan
}

\begin{abstract}
SUMMARY. Academic libraries traditionally provide document delivery services to the campus-based community. Academic fee-based information services accept document requests from corporate, industrial, and professional clients who are willing to pay for a value-added service that includes rush handling, delivery to a third party, or locating an item with a vague citation. The Purdue University Libraries' Technical Information Service (TIS) has grown into a successful venture by developing staff with specialized skills to identify, locate, obtain, and distribute increasingly difficult document orders with short turnaround times. There are advantages to the parent academic library, especially the Interlibrary Loan (ILL) unit, in having a fee-based service to which time-consuming, unusual or expensive requests can be referred. With the potential to increase these advantages comes the need to define clearly the respective roles of these units. [Article copies available for a fee from The Haworth Document Delivery Service: 1-800-342-9678. E-mail address: getinfo@haworthpressinc.com]
\end{abstract}

Most academic libraries limit document delivery services, whether intracampus delivery of locally owned items or traditional interlibrary

Suzanne M. Ward is Head, Access Services, and Mary Dugan is Information Specialist, Technical Information Service, both at the Purdue University Libraries, West Lafayette, IN.

Address correspondence to: Suzanne M. Ward, Head, Access Service, Purdue University Libraries, 1533 Stewart Center, West Lafayette, IN 47907-1533 (E-Mail: ward@purdue.edu).

[Haworth co-indexing entry note]: "Document Delivery in Academic Fee-Based Information Services." Ward, Suzanne M., and Mary Dugan. Co-published simultaneously in The Reference Librarian (The Haworth Press, Inc.) No. 63, 1999, pp. 73-81; and: Document Delivery Services: Contrasting Views (ed: Robin Kinder) The Haworth Press, Inc., 1999, pp. 73-81. Single or multiple copies of this article are available for a fee from The Haworth Document Delivery Service [1-800-342-9678, 9:00 a.m. - 5:00 p.m. (EST). E-mail address: getinfo@haworthpressinc.com].

(C) 1999 by The Haworth Press, Inc. All rights reserved. 
loan (ILL) services, to that group of people defined as the libraries' primary clientele. The primary clientele generally consists of people either enrolled or employed at the institution. Some libraries further restrict certain document delivery services to certain categories of patrons. Intracampus document delivery services might only be available for faculty, for example, or undergraduates might be excluded from ordering material through ILL.

Many academic libraries make no provision for obtaining materials for non-primary users. The reason for this exclusion is certainly understandable. Most academic libraries are hard-pressed to meet the document needs of their primary users in an efficient, cost-effective manner, without also taking on requests from potentially hundreds or thousands of alumni, citizens, or businesspeople throughout the state, region, country, or world. However, some academic libraries have looked for ways to serve these non-primary users without diminishing their ability to meet their primary obligation to the campus patrons. One effective solution for meeting this user need is to establish a cost recovery fee-based information service.

\section{FEE-BASED INFORMATION SERVICES}

A fee-based information service is a library unit that offers several services, usually document delivery and research, to non-primary users. The users are generally businesspeople, but also include entrepreneurs, consultants, corporate librarians, state agencies, trade associations, information brokers, commercial document suppliers, and medical or legal professionals. Services are offered on a cost recovery basis, although a few fee-based services strive to realize a profit. The unit is generally staffed by a combination of professional information specialists and support staff. With the possible exception of the manager or unit head, who may have a split assignment in another area of the library, the staff work exclusively for the service. A fee-based information service essentially offers on-demand corporate library services for companies too small to have their own library or for individuals who prefer to pay for professional research and document delivery services rather than spending the time to track down information or articles on their own. Although research services are an important, and often integral, component of a fee-based information service, this article focuses on document delivery. The authors' experience is 
with Purdue University's Technical Information Service (TIS), a feebased service originally established in 1987 to meet the information needs of Indiana manufacturers. Over the years, TIS' mission has gradually changed. Although a high percentage of clients are still Indiana businesspeople, TIS serves people and firms all over the country and all over the world. Document delivery accounts for about three quarters of TIS' revenue. Most clients request photocopies of articles, patents, or other short documents, but TIS also lends books to clients with addresses in North America.

\section{A SMALL BUSINESS IN A LIBRARY SETTING}

A large part of TIS' success depends on its ability to respond quickly to document requests. For regular delivery, staff ship orders for locally owned materials the day after the request arrives. Orders for rush delivery are filled within a few hours. Corporate clients often have very short deadlines, and are willing to pay premium prices for just-in-time document delivery. They also have an ever-growing array of document suppliers from which to choose, so a fee-based service that cannot meet or beat the competition's turnaround times will experience a dwindling client list.

A rapid response is not the only key to an effective and successful fee-based service. Staff must also develop the expertise to:

- verify citations quickly and cost effectively

- ship materials to third parties

- use a variety of express shippers

- prepare international shipments

- provide accurate cost quotes

- track orders and provide status reports

- provide superlative customer service

- prepare accurate and timely invoices

A few fee-based information services choose to provide document delivery from their local collection only, but most also undertake to obtain items from other sources as well. For example, only about 75 to 80 percent of TIS' document requests can be satisfied by the Purdue University Libraries' collection. TIS chooses to fill the remaining 20 
to 25 percent of client document requests by ordering them from outside suppliers.

\section{GOING BEYOND THE LOCAL COLLECTION}

Besides a consistently quick response to orders, another major factor in TIS' success has been the staff's expertise in quickly obtaining a wide variety of documents unavailable through traditional sources. Clients frequently order documents that are not held locally, and they are often willing to pay higher fees for the staff to obtain those documents on their behalf from other suppliers. Many of these orders are relatively routine, requiring a traditional OCLC search to identify libraries that hold the material, and then choosing potential vendors from fee-based information services affiliated with selected libraries. At TIS our first choice for document suppliers is other fee-based services, because our counterparts will:

- fill standard orders quickly

- meet clients' deadlines for rush orders

- notify us promptly if they cannot fill an order

- ship to third parties

- often reciprocate by ordering documents from us for their clients

At TIS we very rarely order material directly from another institution's interlibrary loan department. The regular turnaround time is generally not fast enough, and we also feel it is ethically questionable to request a free or low-cost copy for which we then charge our clients a fee.

Corporate clients request many specialized documents for which no holding library can be identified. Each service's manager decides whether it is cost-effective to continue searching for the material elsewhere. At Purdue's Technical Information Service, we continue the effort to meet clients' document needs. Some of the types of document suppliers we use are:

- publishers

- trade and professional associations

- document brokers who send runners to major libraries that have no fee-based services 
- authors

- government agencies (local, state, regional, and federal)

- research centers

- commercial or quasi-commercial document suppliers that provide specialized materials (e.g., technical reports from NTIS or dissertations from UMI)

In an increasing number of cases, TIS clients request international documents. Although the requests usually include the name of the issuing agency, TIS staff have learned that it is much faster and more cost effective to deal with a single document supplier in each country or group of countries rather than to work directly with many individual foreign publishers, universities, or trade associations. For example, our European document broker is able to obtain a wide variety of papers, government reports, books, dissertations, conference proceedings, industry standards, and other material. We also use document suppliers in Japan, Australia, the United Kingdom, Canada, South Africa, and several other countries. The advantages of using these suppliers include:

- quick response

- the supplier's staff are knowledgeable about obtaining their country's specialized documents

- avoiding language barriers

- getting around time differences for phone calls

- avoiding lengthy negotiations to make shipping and pre-payment arrangements

- receiving one supplier's invoice for several items, rather than several invoices from several suppliers

- some suppliers bill in U.S. dollars

- possibility that the suppliers reciprocate when they need U.S. documents

\section{DOCUMENT DELIVERY AND THE INTERNET}

In a fee-based information service, the distinction between document delivery and research blurs as more publications become available, often exclusively, on the Internet. With increasing frequency, TIS staff access the Internet as part of the document identification and 
procurement process. We have identified three major uses of the Internet. First, several document vendors list their holdings on the Web and provide options for easily submitting online orders for specific items. CARL UnCover's journal listings and UMI's Dissertation Express sites are two examples. Second, many organizations list their publications on the Internet. By accessing the organization's Web site, TIS staff can quickly verify a document's existence, its price, and contact information for the supplier. Third, in a growing number of cases the document itself may be available more quickly from, or sometimes only from, a Web site.

This third category of Internet access to documents, often involving state or federal documents, is a mixed blessing. Sometimes clients have complete information about a report, but often they can only provide an incomplete or faulty citation, perhaps with only a subject and the name of the issuing agency. For these reasons, the Internet is usually not our first choice as a source for documents. However, sometimes it is the better source and sometimes the only source for these documents as more and more government agencies use the Internet to disseminate information quickly and cheaply.

A call to a state or federal department for either a known or an only vaguely identified document may yield any of these responses:

- the report is not yet available but information about it is included on the department's home page

- the department has all of its current reports listed in a keywordsearchable bibliography available through its home page, and the information included (such as report number) is necessary to order the document

- the document is out of print and a reprint is unlikely, but an electronic version is available on the Internet

- the report is available in print, but since it is out of date, the department prefers that users consult the updated Web version

- the report is only available on the Internet

Electronic document procurement via the Internet may provide instant access, but electronic access presents a number of challenges. Setbacks include messages that the Universal Resource Locator (URL) does not exist or that the server may be down. Having located the producing site's home page, the searcher may still spend a lot of time clicking through link after link to reach the required document. 
Once the document is located, there can be further problems. For example, TIS recently received a request for a 500-page report only available on the Internet. The originating agency provided the exact Web address so we located it immediately. However, printing such a massive document crashed our local area network's server, requiring an emergency visit from the Libraries' computer support unit.

These examples of rapid, cost-effective, efficient, and professional document delivery from the local collection, from other U.S. collections and sources, from international sources, and from electronic sources demonstrate that document delivery in fee-based services must be as comprehensive, integrated, and seamless as possible. Corporate clients are willing to pay the costs (within reason) for just-intime document delivery. Since these clients have many choices of fee-for-service organizations, an academic fee-based service must distinguish itself by its ability to identify, locate, obtain, and distribute increasingly difficult document orders with increasingly shorter turnaround times.

\section{ADVANTAGE TO THE ACADEMIC COMMUNITY}

The specialized skills that fee-based information service staff develop to meet the document needs of their corporate clients can be put to good use by the parent library. The Purdue Libraries have explored some of these options, but the possibility exists of extending the arrangement even further.

The Purdue Libraries Access Services Department consists of four units, two of which are Interlibrary Loan and the Technical Information Service. ILL staff routinely refer to the Technical Information Service the following types of document requests:

- from for-profit organizations

- from international addresses (except Canada)

- from individuals

- from institutions requiring rush delivery services, with the exception of those institutions with which the Purdue Libraries have reciprocal lending arrangements

- from local patrons for material that is unavailable through traditional ILL sources or from the limited number of other sources 
ILL uses, e.g., military specifications or technical reports available only from the issuing organization

These requests either fall outside the scope of ILL services, or are specialized services for which the Purdue Libraries assess a fee. The fee-based service is staffed, organized, and experienced to identify, provide cost quotes, process any necessary pre-payments, fill, deliver, and bill these types of requests.

The ILL unit could further draw on TIS resources by calling on the staff's expertise to handle transactions such as:

- verifying citations in commercial databases

- obtaining documents available only from the issuing agency or from commercial suppliers that ILL does not use

- obtaining selected international documents

- expediting requests from local patrons for rush delivery

- identifying and downloading documents available only on the Internet or from full-text databases

Rather than developing similar skills in both the ILL and the feebased service, the library could decide to eliminate the duplication and outsource the more unusual ILL requests to the fee-based service. The ILL staff would then be able to concentrate their efforts on the evergrowing numbers of relatively straightforward requests.

In making this decision, issues to consider include:

- Definition. Does a policy clearly describe what types of requests will be handled by each unit?

- Loss of expertise. Does the ILL staff lose the opportunity to develop the expertise of handling difficult requests?

- Identify the client. Does the fee-based service obtain items for the ILL unit, or for the individual patron?

- Fees and billing. Does the library reimburse the fee-based service at its published rates (typically the document cost plus a standard handling fee)? Or does the fee-based service handle these orders at a discount from its regular rates? If so, can it still cover its costs? If the transaction is one for which the patron would have paid, does the fee-based service bill the library, or does it bill the end user? If it bills the user, does it charge its regular rates, or a discounted rate? If it charges the patron the discounted rate, does the library make up the difference? 
- Copyright. A fee-based service might pay copyright, or obtain material from a supplier who pays copyright, in cases where the ILL unit would have ordered it under the fair use provisions of the copyright law. Does the user category (campus patron or corporate customer) have a bearing on copyright? Who pays the copyright fees?

- The fee-based service's mission and capacity. A fee-based service's mission is generally to serve off-campus business professionals. Will handling these specialized requests from ILL diminish the ability to provide fast, responsive service to corporate clients? Or can the fee-based service expand to accommodate requests from both the internal and the external sources?

- Status reports. If a campus patron asks ILL staff for the status of a request which was referred to the fee-based service, can the question be answered quickly and accurately?

- Other library staff. Does the rest of the public services library staff understand how and why distinctions are made about which unit handles which kinds of requests? Do they refer patrons appropriately?

The main objective of any document delivery activity is to obtain the material quickly for the patron and at a reasonable cost. There are a number of ways that a library's fee-based information service can act as an outsourcing agent for its own institution's ILL department under certain clearly defined conditions. Thus the fee-based service staff draw on their specialized knowledge and document supplier network to fill some academic community's information needs, without diminishing their ability to meet the information needs of their own clientele. 